\title{
Clinical supervision: What do the supervisors and residents think?
}

1. BDS, M.Phil, MHPE

Assistant Professor/Head Oral

Pathology

Watim Medical and Dental College,

Islamabad.

2. BDS, MPH, MMEd, FHEA,

MAcadMEd, FDTFEd,

PhD. (Medical Education)

Assistant Professor

Institute of Health Professions

Education and Research,

Khyber Medical University,

Peshawar.

3. BSN, DipCard, MHPE

Senior Lecture

Shifa College of Nursing,

Shifa Tameer-e-Millat University,

Islamabad.

4. MBBS

Trainee Medical Officer Khyber Teaching Hospital,

Peshawar.

Correspondence Address:

Gideon Victor

Shifa Tameer-e-Millat University

Pitras Bukhari Road H-8/4, Islamabad

Pakistan.

victorgideon@gmail.com

Article received on:

18/02/2020

Accepted for publication:

$13 / 09 / 2020$

\section{Gulmina Saeed Orakzai ${ }^{1}$, Ahsan Sethi², Gideon Victor ${ }^{3}$, Hira Shireen Aamir ${ }^{4}$}

ABSTRACT... Objectives: To assess the clinical supervisors' performance in the workplace as perceived by themselves and their trainees to determine their educational needs. Study Design: Multisite Descriptive Cross-sectional Survey. Setting: Department of Medicine, Surgery and Dentistry at nine Public and Private Teaching Hospitals of Rawalpindi/lslamabad. Period: $1^{\text {st }}$ March 2018 till $31^{\text {st }}$ January 2019. Material \& Methods: Data were collected from clinical supervisors and their trainees using modified Maastricht Clinical Teaching Questionnaire (mMCTQ) to assess clinical supervisors' modelling, coaching, scaffolding, articulation, Reflection, exploration, and learning climate for trainees' clinical practice. Results: A total of 37 supervisors and 135 trainees participated in the study. The overall agreement was low on observing multiple trainee-patient encounters (Mean $=3.64 \pm 1.17 ; 3.24 \pm 1.10$ ), delivering effective feedback (Mean $=3.89 \pm 0.91 ; 3.60 \pm 1.04$ ), discussing rationale for trainees' actions (Mean $=3.92 \pm 0.69 ; 3.65 \pm 0.97$ ) and consistently demonstrating clinical tasks (Mean $=3.97 \pm 0.87$; $3.46 \pm 0.79)$. The trainees significantly $(p<0.05)$ differed from their supervisors' perceptions in their supervisors' abilities to help them become aware of the gaps in their knowledge and skills, ask and also encourage questions, and adjust teaching activities to reach the trainees level of experience. Conclusion: The study highlighted multiple issues with supervision regarding observation of trainee-patient encounters, deliver effective feedback, and demonstrate clinical tasks. The agreement of trainees on their supervisors' educational abilities is lower than that of supervisors. There is a need for structured training with protected time for clinical supervision.

Key words: Clinical Clerkship, Dentistry, Education, Medicine, Training.

Article Citation: Orakzai GS, Sethi A, Victor G, Aamir HS. Clinical supervision: What do the supervisors and residents think? Professional Med J 2020; 27(11):25292536. https://doi.org/10.29309/TPMJ/2020.27.11.4543

\section{INTRODUCTION}

One of the roles of the doctor which has received worldwide recognition is as a supervisor of future doctors. ${ }^{1}$ The Liaison Committee on Medical Education (LCME), which establishes standards for medical schools in the USA, now requires faculty to have an understanding of educational methods and show a longitudinal commitment to educational scholarship. ${ }^{2}$ The General Medical Council (GMC) 'Tomorrow's Doctors' mentions that doctors are responsible for 'developing the skills and practices of a competent teacher if they are involved in teaching. ${ }^{3}$ In addition, they have implemented a 'Recognition and Approval of Trainers' process, ${ }^{4}$ making it mandatory for all named roles involved in educating medical students and trainees to have minimum competencies in education. This shows a trend towards engaging doctors in effective educational practices across the continuum of their undergraduate, postgraduate and continuing medical education.

Clinical supervisors have a critical role in developing competence among their trainees and in improving healthcare outcomes. However, trainees have expressed dissatisfaction over their supervision. They reported experiencing destructive criticism, sarcastic comments and humiliation in front of other staff and patients. ${ }^{5} \mathrm{On}$ the other hand, the role of clinical supervisors in terms of providing clinical services and patient care cannot be overlooked. ${ }^{6}$ The pressures of clinical productivity competes with the time for teaching. ${ }^{7}$ In addition, they sometimes find the role of supervising trainees quite uncomfortable; 
many are unfamiliar with the principles of medical education. The constraints of professional practice do not allow for training as a teacher and most of their didactic skills have been acquired through observation, trial and error and reflection on past experience. ${ }^{8}$ As learning of a trainee doctor is intricately linked to effective clinical supervision, therefore it is pertinent that in addition to clinical expertise, supervisors should have good supervisory teaching skills. ${ }^{9}$ Absence of such skills would result in reduced readiness to supervise, with supervisory styles ranging from extreme passivity to excessive authoritarianism, which are unhelpful. ${ }^{10}$ It is said that an untrained supervisor is a clinician practising beyond the limits of their training and competencies, which is unprofessional. ${ }^{10}$

Clinical supervision is a complex activity occurring in a variety of context, having numerous functions and diverse methods of delivery. ${ }^{11}$ It is different from traditional classroom teaching and occurs in clinical settings with patients. ${ }^{12}$ The complexity of this role makes it hard to precisely define good supervisory practice in clinical setting, hence demands more research to enhance the quality of supervision. ${ }^{13}$ Moreover, it is believed that the faculty development programs are based on expert frameworks without taking into consideration the learning areas of supervisors. ${ }^{6}$ Concerns have been raised over lack of supervision outcomes, training, and research. ${ }^{10}$ Such programs should be realistic, measurable and tailored to suit the needs of individuals, specialities and institutions. ${ }^{14}$ Clinicians also reported inadequate preparedness to supervise trainees and the traditional medical apprenticeship model remains the backbone of clinical training. ${ }^{15}$ Previous studies from Pakistan have explored trainees' satisfaction from postgraduate training. ${ }^{16,17}$ However, there is a paucity of research on clinical supervisors and their supervisory practices. ${ }^{18-20}$ This study will provide an insight into clinical teaching practice and preparedness of clinical supervisors, and way forward for their needful professional development. Hence, objective of this study is to assess the clinical supervisors' performance in the workplace as perceived by themselves and their trainees to determine their educational needs.

\section{MATERIAL \& METHODS}

This multisite descriptive cross-sectional survey was conducted at nine public and private teaching hospitals of Rawalpindi/Islamabad from $1^{\text {st }}$ March 2018 till $31^{\text {st }}$ January 2019. The names of the institutions have been anonymised to protect their identity. We employed universal sampling, where all the supervisors and trainees of these institutions were invited to participate in the study. Participation was voluntary and anonymous.

A pre-validated modified version of Maastricht Clinical Teaching Questionnaire (mMCTQ) ${ }^{21}$ eliciting evaluations of clinical teachers' performance at the workplace was used. The questionnaire includes 24 items with 5-point Likert scale ( $1=$ fully disagree through to $5=$ fully agree). Two versions were developed: self-evaluation questionnaire for supervisors and feedback questionnaire for trainees. To establish validity in the local context, the questionnaires were pilot tested with 10 trainees and two supervisors. Demographic variables were added, and the questionnaires were kept anonymous.

Ethical approval was taken from Watim Medical and Dental College, which was accepted by all other institutions. Administrative approval and permissions were also obtained from relevant institutional/departmental heads. All the clinical supervisors $(n=40)$ and trainees $(n=150)$ of various medical and dental specialities from nine public and private teaching institutions/ hospitals of Rawalpindi/lslamabad were invited to participate in the study. The authors distributed the participant information sheet along with the questionnaire to the supervisors and their trainees. Participation was voluntary and the participants expressed consent by completing and returning the questionnaire. The authors visited each institution after one week of questionnaires distribution to collect the completed ones and distribute more questionnaires to the available supervisors and trainees. The questionnaires were continuously distribution and collected. Each institute was visited four times to ensure maximum response rate. 
Questionnaires were sequentially numbered. The data were entered into SPSS v.23. Descriptive statistics (frequency, percentage, mean and standard deviation) were calculated. As the data were not normally distributed (ShapiroWilk test $p<0.000$ ), therefore, Mann-Whitney $U$ test was applied to compare educational needs as perceived by supervisors and trainees by specialty, experience as supervisor and institution type.

\section{RESULTS}

A total of 37 supervisors and 135 trainees from nine different institutions participated in the study. Most of the supervisors were male 22 (59.5\%), and from medicine and private-sector institutes. Half of the supervisors aged $42 \mathrm{yrs}$. or above 19 (51.3\%). Only eight supervisors had postgraduate qualifications in medical education. The trainees were predominantly females 76 (56.3\%) and from public-sector institutes. Vast majority of the trainees 103 (76.3\%) aged 26-33 years. Table-l.

Table-II shows the mean agreement and differences on clinical supervisors' performance at the workplace among supervisors/trainees, respondents from different specialty, levels of supervisory experience and institutions. The overall agreement was low on observing multiple trainee-patient encounters (Mean $=3.64 \pm 1.17$; 3.24 \pm 1.10 ), delivering effective feedback (Mean $=3.89 \pm 0.91 ; \quad 3.60 \pm 1.04$ ), discussing rationale for trainees' actions (Mean $=3.92 \pm 0.69$; $3.65 \pm 0.97)$ and consistently demonstrating clinical tasks (Mean $=3.97 \pm 0.87 ; 3.46 \pm 0.79$ ). The mean agreement of trainees on their supervisors' educational abilities was lower than that of their supervisors' and there were many significant differences between the respondent groups. Most of the differences were found in supervisors' ability to show respect to the students (supervisortrainee mean difference $=0.97$ ), stimulating them to consider their strengths and weaknesses $(0.84)$, and having genuine interest in them (0.79).

The trainees significantly differed $(p<0.05)$ from their supervisors' perceptions in their supervisors' abilities to help them become aware of the gaps in their knowledge and skills, ask and also encourage questions, and adjust teaching activities to reach the trainees level of experience. Other significant differences in opinion included in areas like demonstration of clinical tasks, serving as a role model, observing trainee-patient encounters and supporting trainee when they experience difficulty to perform, encouraging them to pursue learning new things and goals, creating safe learning environment.

Trainees in various specialties of medicine and surgery significantly experienced more respect from their supervisors as compared to dentistry trainees. Their supervisors facilitated them to improve their strengths and weaknesses. The experienced supervisors were generally reported to be better than those having less experience. They were significantly better in delivering feedback on trainee-patient encounters, encouraging and asking questions to help increase trainees' understanding. The supervisors in public or private institutions were reported similar, except in offering opportunities to perform task independently and support when the trainees experienced difficulty, where supervisors from public-sector were significantly better ( $p$-value $<0.05$ ).

\section{DISCUSSION}

This is the first multisite study from Pakistan that assessed the educational needs of clinical supervisors as perceived by themselves and their trainees. We found gender related difference in our study with male supervisors outnumbering female supervisors, while female trainees out numbering male trainees. This suggest that many females do not pursue necessary requirements to become supervisors in their careers. This may be related to the socio-cultural environment and gender inequalities in our part of the world. ${ }^{22}$

This demands proactive measures from the government and institutes ensuring gender equity. 


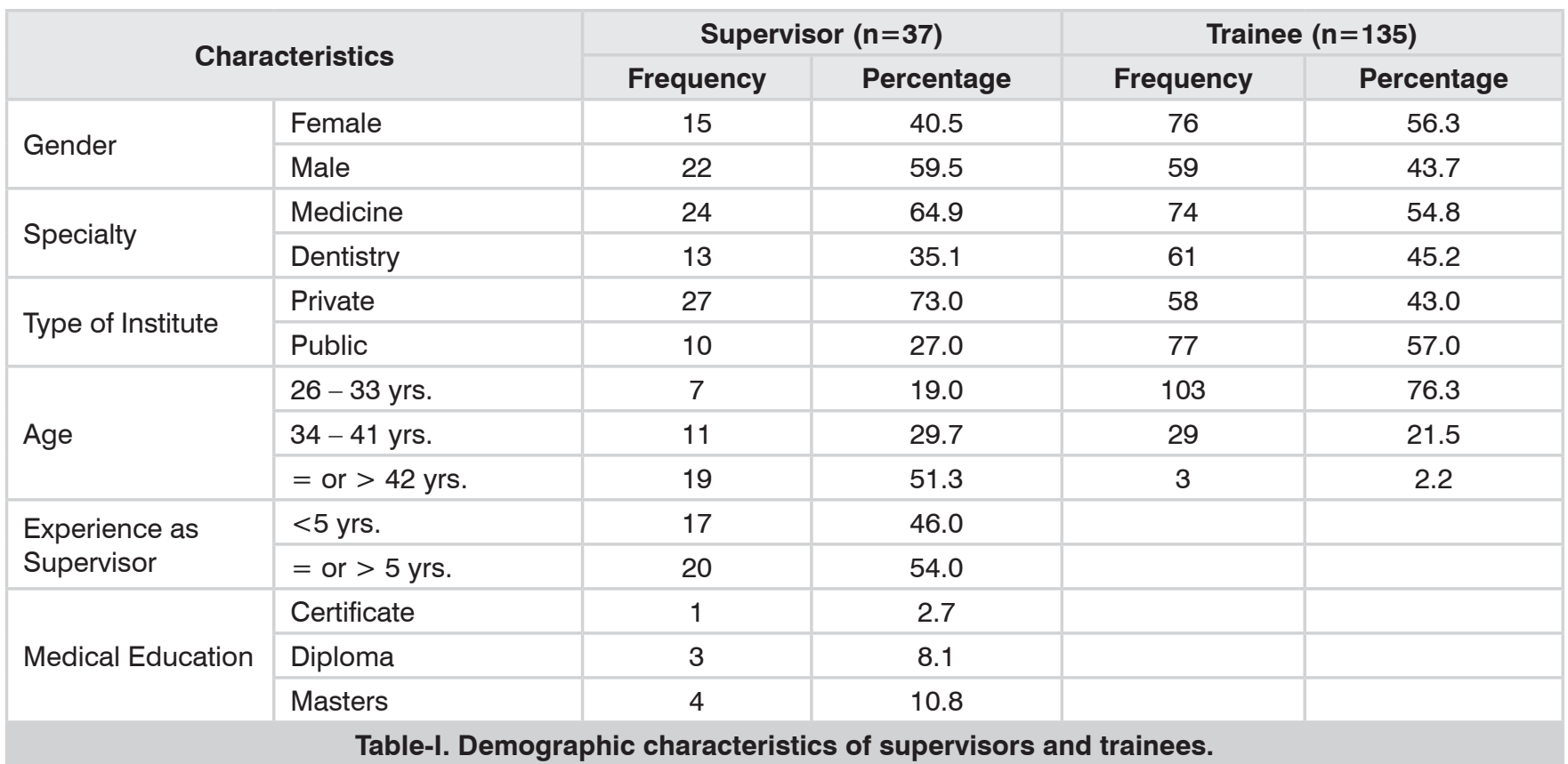

A few clinical supervisors having postgraduate qualifications in medical education also suggest their expressed needs for developing the competencies required of a clinical supervisor. ${ }^{15}$ These postgraduate qualifications in medical education have been reported to improve theoretical foundations in educational practices, along with development as teacher, leader, researcher and learner. ${ }^{23,24}$

The role of clinical supervisor and their supervisory practices is under debate worldwide. ${ }^{20}$ We found low overall agreement on supervisors' ability to observe trainee-patient encounters on multiple occasions, deliver effective feedback, discuss rationale for trainees' actions and demonstrate clinical tasks consistently. These results are in line with other studies conducted by Hameed et al and Mahmood et al $^{16,17}$ in Pakistan. The clinical workplace is considered a temporary and brief source of learning with a complex imbalance of supply (access to skills training and teachers) and demands (learning needs of the student). ${ }^{25}$ The significant difference between the ratings could be due to workload of the clinical teachers in our public and private-sector hospitals, which hampers their clinical teaching proficiency and ultimately hinders their trainees learning process. $^{26}$
The supervisors reported satisfaction with regards to showing respect to their trainees, stimulating them to consider their strengths and weaknesses during supervision, asking and encouraging questions from trainees and having genuine interest in their professional growth. However, the trainees' satisfaction on their supervisors' educational abilities was lower than that of their supervisors' and there were many significant differences between the respondent groups. The gap between resident and faculty perceptions has been reported by Jensen and colleagues ${ }^{27}$ as well, who looked at educational feedback in the clinical settings.

Despite the challenges, we recommend that structured postgraduate training with protected time for demonstration, training, observing trainee-patient encounters and delivering effective feedback. This might require considerations for allowing more than one supervisor for each trainee as in UK e.g. ${ }^{4}$ clinical supervisors for day-to-day supervision in the workplace and one educational supervisor, who ensures that trainees are making the necessary clinical and educational progress overtime. 


\begin{tabular}{|c|c|c|c|c|c|c|c|}
\hline \multirow{2}{*}{ S\# } & \multirow{2}{*}{ Questionnaire Items } & \multirow{2}{*}{$\begin{array}{l}\text { Supervisor } \\
\text { ( } \mathrm{n}=37) \\
\text { Mean } \\
\text { (SD) }\end{array}$} & \multirow{2}{*}{$\begin{array}{c}\text { Trainee } \\
(\mathrm{n}=135) \\
\text { Mean } \\
\text { (SD) }\end{array}$} & \multicolumn{4}{|c|}{ P-Value } \\
\hline & & & & $\begin{array}{l}\text { Supervisor/ } \\
\text { Trainees }\end{array}$ & $\begin{array}{l}\text { Medicine/ } \\
\text { Dentistry }\end{array}$ & $\begin{array}{l}\text { Experience as } \\
\text { Supervisor }\end{array}$ & $\begin{array}{l}\text { Public/ } \\
\text { Private }\end{array}$ \\
\hline 1 & $\begin{array}{l}\text { I consistently demonstrate how to } \\
\text { perform clinical tasks }\end{array}$ & $\begin{array}{c}3.97 \\
(0.87)\end{array}$ & $\begin{array}{c}3.46 \\
(0.79)\end{array}$ & $0.001^{*}$ & 0.627 & 0.873 & 0.652 \\
\hline 2 & $\begin{array}{l}\text { I clearly explain important element } \\
\text { for the execution of a given task }\end{array}$ & $\begin{array}{c}4.14 \\
(3.69)\end{array}$ & $\begin{array}{l}3.69 \\
(0.95)\end{array}$ & $0.008^{\star}$ & 0.724 & 0.395 & 0.346 \\
\hline 3 & $\begin{array}{l}\text { I create sufficient opportunity for the } \\
\text { student to observe me }\end{array}$ & $\begin{array}{c}3.97 \\
(1.01)\end{array}$ & $\begin{array}{l}3.48 \\
(1.10)\end{array}$ & $0.005^{\star}$ & 0.763 & 0.741 & 0.577 \\
\hline 4 & $\begin{array}{l}\text { I serve as a role model as to the } \\
\text { kind of health professional students } \\
\text { would like to become }\end{array}$ & $\begin{array}{c}4.11 \\
(1.05)\end{array}$ & $\begin{array}{c}3.50 \\
(1.06)\end{array}$ & $0.003^{*}$ & 0.839 & 0.224 & 0.373 \\
\hline 5 & $\begin{array}{l}\text { I observe students' multiple times } \\
\text { during patient encounters }\end{array}$ & $\begin{array}{c}3.64 \\
(1.17)\end{array}$ & $\begin{array}{c}3.24 \\
(1.10)\end{array}$ & $0.041^{*}$ & 0.248 & 0.829 & 0.648 \\
\hline 6 & $\begin{array}{l}\text { I give useful feedback during or } \\
\text { immediately after direct observation } \\
\text { of the student's patient encounter }\end{array}$ & $\begin{array}{l}3.89 \\
(0.91)\end{array}$ & $\begin{array}{c}3.60 \\
(1.04)\end{array}$ & 0.121 & 0.643 & $0.014^{*}$ & 0.325 \\
\hline 7 & $\begin{array}{l}\text { I help the student understand which } \\
\text { aspects they need to improve }\end{array}$ & $\begin{array}{c}4.31 \\
(0.67)\end{array}$ & $\begin{array}{c}3.73 \\
(0.96)\end{array}$ & $0.001 *$ & 0.456 & 0.776 & 0.164 \\
\hline 8 & $\begin{array}{l}\text { I adjust my teaching activities to the } \\
\text { level of experience of students }\end{array}$ & $\begin{array}{l}4.31 \\
(0.79)\end{array}$ & $\begin{array}{l}3.60 \\
(0.99)\end{array}$ & $0.000^{*}$ & 0.066 & 0.231 & 0.323 \\
\hline 9 & $\begin{array}{l}\text { I offer sufficient opportunities } \\
\text { to students to perform activities } \\
\text { independently }\end{array}$ & $\begin{array}{l}4.14 \\
(0.96)\end{array}$ & $\begin{array}{c}3.52 \\
(1.10)\end{array}$ & $0.002^{*}$ & 0.153 & 0.911 & $0.013^{*}$ \\
\hline 10 & $\begin{array}{l}\text { I support student in activities they } \\
\text { find difficult to perform }\end{array}$ & $\begin{array}{l}4.25 \\
(0.84)\end{array}$ & $\begin{array}{c}3.67 \\
(0.96)\end{array}$ & $0.001 *$ & 0.904 & 0.749 & $0.045^{*}$ \\
\hline 11 & $\begin{array}{l}\text { I gradually reduce support given to } \\
\text { allow students to perform certain } \\
\text { activities more independently }\end{array}$ & $\begin{array}{c}4.06 \\
(1.04)\end{array}$ & $\begin{array}{l}3.85 \\
(0.93)\end{array}$ & 0.139 & 0.707 & 0.148 & 0.209 \\
\hline 12 & $\begin{array}{l}\text { I ask students to provide a rationale } \\
\text { for their actions }\end{array}$ & $\begin{array}{l}3.92 \\
(0.69)\end{array}$ & $\begin{array}{l}3.65 \\
(0.97)\end{array}$ & 0.095 & 0.718 & 0.159 & 0.230 \\
\hline 13 & $\begin{array}{l}\text { I help students become aware of the } \\
\text { gaps in their knowledge and skills }\end{array}$ & $\begin{array}{l}4.36 \\
(0.76)\end{array}$ & $\begin{array}{c}3.62 \\
(1.03)\end{array}$ & $0.000^{\star}$ & 0.052 & 0.665 & 0.919 \\
\hline 14 & $\begin{array}{l}\text { I ask students questions aimed at } \\
\text { increasing their understanding }\end{array}$ & $\begin{array}{c}4.42 \\
(0.87)\end{array}$ & $\begin{array}{l}3.71 \\
(0.86)\end{array}$ & $0.000^{\star}$ & 0.129 & $0.037^{\star}$ & 0.461 \\
\hline 15 & $\begin{array}{l}\text { I encourage students to ask } \\
\text { me questions to increase their } \\
\text { understanding }\end{array}$ & $\begin{array}{l}4.42 \\
(0.81)\end{array}$ & $\begin{array}{l}3.71 \\
(0.98)\end{array}$ & $0.000^{*}$ & 0.784 & $0.019^{\star}$ & 0.070 \\
\hline 16 & $\begin{array}{l}\text { I stimulate students to explore their } \\
\text { strengths and weaknesses }\end{array}$ & $\begin{array}{c}4.22 \\
(0.82)\end{array}$ & $\begin{array}{l}3.60 \\
(0.89)\end{array}$ & $0.000^{*}$ & 0.397 & 0.570 & 0.487 \\
\hline 17 & $\begin{array}{l}\text { I stimulate students to consider how } \\
\text { they could improve their strengths } \\
\text { and weaknesses }\end{array}$ & $\begin{array}{c}4.27 \\
(0.84)\end{array}$ & $\begin{array}{c}3.43 \\
(1.03)\end{array}$ & $0.000^{\star}$ & $0.010^{*}$ & 0.901 & 0.932 \\
\hline 18 & $\begin{array}{l}\text { I encourage students to formulate } \\
\text { learning goals }\end{array}$ & $\begin{array}{l}4.00 \\
(0.97)\end{array}$ & $\begin{array}{l}3.73 \\
(0.98)\end{array}$ & 0.111 & 0.089 & 0.818 & 0.634 \\
\hline 19 & $\begin{array}{l}\text { I encourage students to pursue their } \\
\text { learning goals }\end{array}$ & $\begin{array}{c}4.19 \\
(1.05)\end{array}$ & $\begin{array}{l}3.58 \\
(1.01)\end{array}$ & $0.001^{*}$ & 0.866 & 0.474 & 0.694 \\
\hline 20 & $\begin{array}{l}\text { I encourage students to learn new } \\
\text { things }\end{array}$ & $\begin{array}{c}4.24 \\
(1.09)\end{array}$ & $\begin{array}{c}3.69 \\
(1.01)\end{array}$ & $0.003^{*}$ & 0.183 & 0.765 & 0.227 \\
\hline 21 & I create a safe learning environment & $\begin{array}{l}4.32 \\
(0.91)\end{array}$ & $\begin{array}{l}3.65 \\
(0.98)\end{array}$ & $0.000^{\star}$ & 0.696 & 0.551 & 0.818 \\
\hline 22 & $\begin{array}{l}\text { I take sufficient time to supervise } \\
\text { students }\end{array}$ & $\begin{array}{c}4.03 \\
(1.17)\end{array}$ & $\begin{array}{c}3.62 \\
(1.03)\end{array}$ & $0.024^{\star}$ & 0.833 & 0.794 & 0.858 \\
\hline 23 & $\begin{array}{l}\text { I am genuinely interested in the } \\
\text { students }\end{array}$ & $\begin{array}{l}4.43 \\
(0.96)\end{array}$ & $\begin{array}{c}3.64 \\
(1.00)\end{array}$ & $0.000^{\star}$ & 0.565 & 0.707 & 0.692 \\
\hline 24 & I show respect to students & $\begin{array}{c}4.46 \\
(1.10)\end{array}$ & $\begin{array}{c}3.49 \\
(1.12)\end{array}$ & $0.000^{*}$ & $0.016^{\star}$ & 0.782 & 0.244 \\
\hline
\end{tabular}


The trainees reported dissatisfaction from their supervisors' abilities to develop a safe learning environment, act as a role model, encourage reflection to help trainee become aware their strengths and areas for improvement, encourage questions and adjust teaching activities to reach the trainees level of experience. This was explicitly pointed out in a somewhat similar study where the clinical residents found the available supervision insufficient in these areas. ${ }^{28,17}$ Role modelling is an effective strategy for instilling professional behaviour in trainees through observational learning. ${ }^{29}$ Supervisors should make their implicit behaviour as role model explicit to the trainee, so that they can learn the norms and values of the speciality, and also become motivated and use the modelled behaviour as a guide. ${ }^{6}$ The supervisor trainee relationships should be considered as collegial partnership rather than traditional master-apprenticeship relationship. Learning is enhanced when working as a team. Supervisors should engage the trainees in joint problem-solving, which will create a climate of trust which is further improved if supervisor acknowledges the level of trainee, their current knowledge and shortcomings. ${ }^{6,30}$

It is worth considering here that there is little incentive to supervise trainees, limited formal training in clinical supervision and no emphasis on professional development. Effective supervision should allow for a learning environment that mediates and supports their trainees for better patient outcomes. ${ }^{20}$ Clinical clerks and residents have identified positive attitude, taking time to teach, using teachable moments, tailoring teaching methods to the learner, and giving appropriate feedback as attributes of a good teacher. ${ }^{31}$ We suggest a process for evaluation of supervisors by the trainees, followed by continuous professional development tailored to their educational needs and recertification. In addition, the supervisory training program should encompass the educational, supportive and administrative roles of supervisors. ${ }^{32}$

The study showed that clinical supervisors in various specialties of medicine and surgery showed more respect to their trainees as compared to their fellow clinical supervisors in dentistry. Moreover, their supervisors were more efficient in facilitating their trainees to improve their strengths and overcome weaknesses. Trainees were more satisfied from the experienced supervisors who gave them an effective feedback encouraging reflection from the learners to increase their understanding. This included supervisors with some sort of formal training in medical education. ${ }^{23}$ These findings were similar to another study showing dearth of constructive feedback practices in Pakistan ${ }^{33}$, over emphasizing the role of timely feedback serving as a powerful tool for enhancing trainees' performance. ${ }^{34}$

The supervisors' performance in postgraduate training at public/private-sector institutions was almost similar as also reported in an appraisal of postgraduate medical training in Pakistan. ${ }^{35}$ Supervisors from public-sector institutions offered significantly more opportunities to their trainees to perform clinical task independently and supported them when they experienced difficulty. This could be due to genuine interest of the supervisors in helping their trainees due to job security, better access (central location) and more patient turn over in these hospitals. ${ }^{36}$

The study cannot be generalized as the clinical supervisors and trainees were not representative and from institutes of Rawalpindi/Islamabad, yet it serves an important role of identifying the gaps in clinical environment of many reputable institutes of the country. Future research in other provinces of Pakistan will help the College of Physicians and Surgeons (CPSP) to devise ways to manage clinical education and supervisors' professional development within local constraints. Also, an in-depth qualitative research to explore the educational needs of supervisors will be useful.

\section{CONCLUSION}

This study assesses the clinical supervisors' performance as perceived by themselves and trainees to determine their educational needs. There are multiple issues with supervision including supervisor' inability to frequently observe trainee-patient encounters, deliver effective feedback, 
and demonstrate clinical tasks. The agreement of trainees on their supervisors' educational abilities is lower than that of supervisors. Clinical supervisors in various specialties of medicine and surgery were keener on improving their trainees than those in dentistry. Public-sector institutions offer more opportunities for independent practice to their trainees.

Copyright@ 13 Sep, 2020.

\section{REFERENCES}

1. Frank JR, Snell L, Englander R, Holmboe ES, Collaborators I. Implementing competency-based medical education: Moving forward. Med Teach. 2017; 39(6):568-573.

2. Liaison Committee on Medical Education. Functions and structure of a medical school - standards for accreditation of medical education programs leading to the M.D. Degree 2014 [cited 2014 June 12]. Available from: http://www.lcme.org/publications.htm.

3. Gates AB. Training tomorrow's doctors, in exercise medicine, for tomorrow's patients. Br J Sports Med. 2015; 49(4):207-208.

4. General Medical Council. Recognition and approval of trainers 2012 [cited 2019 October 1]. Available from: http://www.gmc-uk.org/education/10264.asp\#1.

5. Ayyala MS, Rios R, Wright SM. Perceived bullying among internal medicine residents. JAMA. 2019; 322(6):576-578.

6. Bearman M, Tai J, Kent F, Edouard V, Nestel D, Molloy E. What should we teach the teachers? Identifying the learning priorities of clinical supervisors. Adv Health Sci Educ Theory Pract. 2018; 23(1):29-41.

7. Barzansky B, Kenagy G. The full-time clinical faculty: What goes around, comes around. Acad Med. 2010; 85(2):260-265.

8. Ray A, Ray S, Gopi A, Selvakumar D. Assessing domain based teaching skills of postgraduates after a workshop on effective lesson plan. J Educ Tech Health Sci. 2018; 5(2):86-91.

9. Steinert $\mathrm{Y}$, Mann $\mathrm{K}$, Anderson B, Barnett BM, Centeno A, Naismith $L$, et al. A systematic review of faculty development initiatives designed to enhance teaching effectiveness: A 10-year update: BEME Guide No. 40. Med Teach. 2016; 38(8):769-786.

10. Gonsalvez CJ, Milne DL. Clinical supervisor training in Australia: A review of current problems and possible solutions. Aust Psychol. 2010; 45(4):233-242.
11. Farnan JM, Petty LA, Georgitis E, Martin S, Chiu E, Prochaska $M$, et al. A systematic review: the effect of clinical supervision on patient and residency education outcomes. Acad Med. 2012; 87(4):428-442.

12. Bogie BJ, Harms S, Saperson K, McConnell MM. Learning the tricks of the trade: the need for specialty-specific supervisor training programs in competency-based medical education. Acad Psychiatry. 2017; 41(3):430-433.

13. Goldie J, Dowie A, Goldie A, Cotton P, Morrison J. What makes a good clinical student and teacher? An exploratory study. BMC Med Educ. 2015; 15(1):40-47.

14. Shah N, Tabassum A, Shah N. A needs assessment for faculty development at two medical colleges of Dow University of Health Sciences, Karachi. Pak J Med Sci. 2018; 34(6):1386-1391.

15. Tai J, Bearman M, Edouard V, Kent F, Nestel D, Molloy E. Clinical supervision training across contexts. Clin Teach. 2016; 13(4):262-266.

16. Hameed T, Zia N, Khan HS, Zia A, Ahmed R, Hameed A, et al. Analysis of level of satisfaction of postgraduate trainee on surgical floor. J Ayub Med Coll Abbottabad. 2019; 31(2):207-213.

17. Mahmood S, Khaliq T, Raza A. Post Graduate medical training in Pakistan. Pak Armed Forces Med J. 2018; 68(4):807-811.

18. Stephan A, Cheung G. Clinical teaching and supervision in postgraduate psychiatry training: The trainee perspective. Australas Psychiatry. 2017; 25(2):191-197.

19. MacDonald J, Ellis PM. Supervision in psychiatry: Terra incognita? Curr Opin Psychiatry. 2012; 25(4):322326.

20. Strand P, Edgren G, Borna P, Lindgren S, WichmannHansen G, Stalmeijer RE. Conceptions of how a learning or teaching curriculum, workplace culture and agency of individuals shape medical student learning and supervisory practices in the clinical workplace. Adv Health Sci Educ Theory Pract. 2015; 20(2):531-557.

21. Stalmeijer RE, Dolmans DH, Wolfhagen $I H$, Muijtjens AM, Scherpbier AJ. The Maastricht Clinical Teaching Questionnaire (МСTQ) as a valid and reliable instrument for the evaluation of clinical teachers. Acad Med. 2010; 85(11):1732-1738.

22. Malik S, Courtney K. Higher education and women's empowerment in Pakistan. Gend Educ. 2011; 23(1):2945. 
23. Sethi A, Schofield S, Ajjawi R, McAleer S. How do postgraduate qualifications in medical education impact on health professionals? Med Teach. 2016; 38(2):162-167.

24. Sethi A, Schofield S, McAleer S, Ajjawi R. The influence of postgraduate qualifications on educational identity formation of healthcare professionals. Adv Health Sci Educ Theory Pract. 2018; 23(3):567-585.

25. Calkins S, Johnson N, Light G. Changing conceptions of teaching in medical faculty. Med Teach. 2012; 34(11):902-906.

26. Yepes-Rios M, Dudek N, Duboyce R, Curtis J, Allard RJ, Varpio $L$. The failure to fail underperforming trainees in health professions education: A BEME systematic review: BEME Guide No. 42. Med Teach. 2016; 38(11):1092-1099.

27. Jensen AR, Wright AS, Kim S, Horvath KD, Calhoun $\mathrm{KE}$. Educational feedback in the operating room: a gap between resident and faculty perceptions. Am J Surg. 2012; 204(2):248-255.

28. Scarff CE, Bearman M, Chiavaroli N, Trumble S. Keeping mum in clinical supervision: Private thoughts and public judgements. Med Educ. 2019; 53(2):133-142.

29. Jochemsen-van der Leeuw HR, van Dijk N, van EttenJamaludin FS, Wieringa-de Waard $M$. The attributes of the clinical trainer as a role model: A systematic review. Acad Med. 2013; 88(1):26-34.
30. Finn KM, Metlay JP, Chang Y, Nagarur A, Yang S, Landrigan CP, et al. Effect of Increased Inpatient Attending Physician Supervision on Medical Errors, Patient Safety, and Resident Education: A Randomized Clinical Trial. JAMA Intern Med. 2018; 178(7):952-959.

31. Bandiera GW, Lee S. Strategies for effective clinical emergency department teaching. In: R. L. Rogers AM, M. E. Winters, J. P. Martinez and T. M. Mulligan, editor. Practical Teaching in Emergency Medicine. 2nd ed: John Wiley \& Sons; 2013. 337-351.

32. Hauer KE, Oza SK, Kogan JR, Stankiewicz CA, Stenfors $\square$ Hayes T, Cate Ot, et al. How clinical supervisors develop trust in their trainees: a qualitative study. Med Educ. 2015; 49(8):783-595.

33. Hamid Y, Mahmood S. Understanding constructive feedback: A commitment between teachers and students for academic and professional development. J Pak Med Assoc. 2010; 60(3):224-227.

34. Ramani S, Krackov SK. Twelve tips for giving feedback effectively in the clinical environment. Med Teach. 2012; 34(10):787-791.

35. Biggs JS. Postgraduate medical training in Pakistan: observations and recommendations. J Coll Physicians Surg Pak. 2008 Jan 1;18(1):58-63.

36. Sethi $A$, Khan $A$. Is the dental clinical learning environment suitable? A survey of Khyber Pakhtunkhwa, Pakistan. J Pak Med Assoc. 2018; 68(3):359-363.

\begin{tabular}{|c|c|c|c|}
\hline \multicolumn{3}{|c}{ AUTHORSHIP AND CONTRIBUTION DECLARATION } \\
\hline Sr. \# & Author(s) Full Name & \multicolumn{1}{|c|}{ Contribution to the paper } & Author(s) Signature \\
\hline 1 & Gulmina Saeed Orakzai & $\begin{array}{l}\text { Conceived the idea, designed the study, } \\
\text { obtained ethical approval, collected data } \\
\text { and ensured its integrity, Manuscript } \\
\text { writing and final approval. } \\
\text { Conceived the idea and designed the } \\
\text { study, data analysis and interpretation. } \\
\text { Manuscript writing and final approval. } \\
\text { Was involved in data analysis, data } \\
\text { interpretation, writing the manuscript and } \\
\text { its final approval. } \\
\text { Was involved in data analysis, data } \\
\text { interpretation, writing the manuscript and } \\
\text { its final approval. }\end{array}$ \\
\hline 3 & Ahsan Sethi & Gideon Victor & Hira Shireen Aamir
\end{tabular}

